\title{
Studies on a Biological Action of Synthetic Hypothalamic Hormone TRF
}

1. Effect of synthetic TRF in vivo and in vitro

\author{
Masahiro SAKODA, Tsuneo FUKUDA, Masanori TAMAOKA, \\ Hiroyoshi FUKATSU and Toshio OKUBO
}

2nd Department of Internal Medicine, Kobe University School of Medicine

Although the chemical nature and structure of TRF (Thyrotropin-Releasing Factor) has been discussed and studied for 10 years, it is in not quite clear. In 1969 Folkers had synthesized a tripeptide, pyroglutamylhistidilyproline amide, based on knowledge of chemical nautre obtained earlier and observed distinct TRF activity of this tripeptide.

However, there remained to be studied in details the biological action of synthestic TRF. Since we have received synthestic TRF preparation from Dr. Folker, the studies concerning biological action of synthetic TRF were performed in vivo and in vitro. Three assay systems for detecting TRF activity were adopted in vivo using rat or mice and in vitro using rat pituritay incubation.

1. TRF assay by estimation of rat plasma TSH

$\mathrm{T}_{4}$-pretreated male rats of Swiss-Webster strain weighing $120-130 \mathrm{~g}$ were used. Under pentbarbital anesthesia synthetic TRF was injected into the jugular vein. Blood was collected at 10 and 12 minutes after the injection, and plasma TSH was measured by McKenzie's method. 1.0, 5.0 and $10.0 \mu \mathrm{g}$ of synthetic TRF induced the most prominent increase of plasma TSH at $10 \mathrm{~min}$. after the injection respectively. A clear dose-response relation was recognized between the doses ranging from 1.0 to $10.0 \mu \mathrm{g}$ of synthetic TRF, and plasma TSH was found to be increased with each TRF doses.

2. TRF assay by estimation of mouse blood ${ }^{131} \mathrm{I}$ levels.

As reported by Redding, $5 \mu \mathrm{Ci}$ of $\mathrm{Na}^{131} \mathrm{I}$ and $1.0 \mu \mathrm{Ci} \mathrm{T}_{4}$ were administered to mice of D D strain weighing 13-15 g. Blood radioactivity was checked before and $2 \mathrm{hrs}$. after administration of synthetic TRF on the 3rd day of experiment. In this assay 50 and $100 \mathrm{ng}$ of synthetic TRF increased blood radioactivity.

3. TRF assay in vitro using short term incubation of rat pituitary.

Three halves of rat anterior pituitaries were placed in one flask and incubated by modified Saffran's technique, one flask for the test and the other as control. $1.0 \mathrm{ug}$ of synthetic TRF were added ot the incubation medium. A distinct increase of TSH activity in the medium was observed after 60 minutes' incubation. From these findings described above, synthetic TRF (pyroglutamilhistidilproline amide) has a prominent TRF activity both in vivo and in vitro.

(See pp. 821 825) 


\title{
Studies on a Biological Action of Synthetic Hypothalamic
} Hormone TRF

2. Specificity and modifying factor of synthetic TRF action

\author{
Masahiro SAKODA, Makoto OTSUKI, Takaaki KUSAKA, \\ Hidetaro MORI, and Takashi MINEYAMA
}

2nd Department of Internal Medicine, Kobe University School of Medicine

Recently a number of neuroendocrinological studies have revealed that releasing factor (RF) plays an essential role in the regulation of pituitary tropic hormone secretion. Though a fastinating problem about chemical structure of TRF has long been obscure, Folkers and his collegues had synthesized a preparation called pyroglutamilhistidilproline amide which has distinct TRF activity both in vivo and in vitro.

Using this synthetic TRF preparation received from Dr. Folkers, prominent effects were observed in rat and mouse as reported before by us. However, it is very important whether these actions of synthtic TRF are specific or not, and also whether there may exist modifying factors of TRF action or not. From the these points of view, the following experiments were performed.

1. Specificity of action of synthetic TRF

$10.0 \mu \mathrm{g}$ of synthetic TRF induced the most prominent increase in rat plasma TSH at 10 minutes after i.v. injection. On the contrary, no TRF effect was observed when $10.0 \mu \mathrm{g}$ of synthefic TRF was given to the mice directly, showing absence of TSH or TSH like activity in synthetic TRF. TSH effect was found to be not altered when synthtice TRF was administered, mixed with a known amount of beef TSH preparation. These findings may indicate that there is no TSH like activity or potentiation of TSH in synthetic TRF.

2. Influence of thyroxine on synthetic TRF activity.

We studied the pituitary responsivenees to synthetic TRF in $T_{4}$ pretreated rats. Plasma TSH levels at 10 minutes after injection of synthetic TRF were estimated in rats pretreated with various doses of L-thyroxine $\mathrm{Na} 4 \mathrm{hrs}$ previously. The rats pretreated with $3.0 \mu \mathrm{g}$ of $\mathrm{T}_{4}$ showed no TSH increase after administration of $1.0 \mu \mathrm{g}$ synthetic TRF, whereas the rat treated with $3.0 \mu \mathrm{g}$ of $\mathrm{T}_{4}$ showed distinct TSH increase when $10.0 \mu \mathrm{g}$ of syntheitc TRF was administrated. However, $10.0 \mu \mathrm{g}$ of synthetic TRF could not evoke $\mathrm{TSH}$ increase when rats received $10.0 \mu \mathrm{g}$ of $\mathrm{T}_{4}$. It was concluded that there is a dose dependent negative interaction between synthetic TRF and thyroxine in regulation of pituitary TSH secretion.

(See pp. 826 829) 


\title{
合成視床下部ホルモン TRF (Thyrotropin-Releasing \\ Factor）の生物作用にかんする研究
}

\author{
第 1 篇 in vivo, in vitro に拉りる合成 TRF の効果 \\ 神戸大学医学部第 2 内科 \\ 佐古田 雅 弘, 福田恒夫 \\ 玉岡昌則, 深 津泰良 \\ 大久保 理 夫
}

（昭和45年 7 月 1 日受付）

従来 TRF の化学構造について不詳の点が多かつたが Folkers らの合成になる Tripeptide (pyroglutamylhistidilproline Amide) の TRF 作用を検討した。この合成 TRF はマウス,ラットを使用 した in vivo の検定，ラット下垂体による in vitro の検定の両者で明らかな TRF 作用を有する事 を観察した. 同時に in vivo では合成 TRF 投与量と TSH 放出反応との間に用量反応関係を有し， 投与後10分でピークを示す TSH 放出の時間経過を示した.

\section{I 緒言}

中枢神経系による下垂体前葉分泌の調節機序として視床下部起源の液性因子が想定されて既に久しいがて の Releasing Factor (RF) の化学的本態については必ずしも明らかでなかつた. Thyrotropin Releasing Factor (TRF) そついても1966年に Schally, Guillemin らによつて 3 種類の構成アミノ酸が明らかにされて いたが TRF の化学構造は不明のまま残されていた. 1969年秋に Folkers らは従来の TRF にかんする構 造特性に基いて Tripeptide を合成し，その TRF 作用について一部を報告しているが詳細は明らかでな い.

吾々は Folkers より彼らが合成した TRF preparation の提供を受けその生物作用について検討する機会 を得たのでとこにその結果を報告する．

\section{II 実 験 方 法}

\section{1. 実験動物}

体重 13-15g のDD系雌マウス, 体重 120-130g の Swiss Webster 系雄ラットを低ヨード含有飼料及び 蒸溜水にて飼育したものを用いた。

2. TRF 検定法

a) in vivo マウス法：ラベル甲状腺ホルモン放出による血中放射能変動を指樌とする Redding ${ }^{1}$ 変法によ つた. 即ち実験 2 日前に $5 \mu \mathrm{ci}$ の ${ }^{131} \mathrm{I} \mathrm{Na}$ を腹腔内投与， 1 日前に $\mathrm{T}_{4} 1.0 \mu \mathrm{g}$ を皮下注し実験当日前採血の のち検体を静注し 2 時間後再度採血して両者の Bloodradioactivity を測定, 増加率を\%で表した。

b) in vivo ラット法：血獎 TSH の変動を指標とする佐古田 ${ }^{2}$ の方法によつた． 即ち実験 4 時間前に $\mathrm{T}_{4}$ $0.4 \mu \mathrm{g} / 100 \mathrm{~g}$ 体重を皮下注射しペントバルビタール林酔下に頸静脈より検体投与後10分で採血し TSH 検定 に供した. 
c) in vitro 法（下垂体短時間インクベーション法）：Saffran ${ }^{3)}$ 変法によつた。 即ち 3 頭からのラット下 垂体前葉を狭部にて正確に 2 等分し Krebs-Ringer-Bicarbonate-Glucose (200mg/d1)-Buffer（以下 KRBG と略す）(pH=7.2） $2 \mathrm{ml}$ を入れた容量 $25 \mathrm{ml}$ の 2 つのフラスコに夫々 3 半切片を別々に入れ実験群及び対照 群とした. $95 \% \mathrm{O}_{2}-5 \% \mathrm{CO}_{2}$ にてフラスコを充し $37^{\circ} \mathrm{C}$ に60分の Preincubation を行なつたのち下垂体を別 のフラスコに入れ実験群には検体を添加した KRBG 夜にて Finalincubation を60分行ない Medium 内 の TSH 活性を実験群と対照群で比較した. (paired incubation)

\section{TSH 測定法}

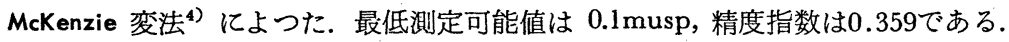

4. 合成 TRF

Dr. Folkers の合成)提供によるもの (IBR 228, Institute for Biomed Research, Univ. of Texas) で構 造は Pyroglutamylhistidilproline amide [(pyro) Glu-His-Pro( $\left.\mathrm{NH}_{2}\right)$ ] (Fig. 1) であり使用に際しては生 理食塩水に溶解した。

Fig. 1<smiles>NC(=O)C1C2NCC(N2)C1C(NC(=O)C1CCC(=O)N1)C(=O)N1CC[CH]C1C(N)=O</smiles>

\section{5. 結果の推計学的処理}

In vivo, in vitro で放出された TSH の検定には 1 群 6-8 匹のマウスを使用し群間の差の検証は Student の $\mathrm{t}$ test そよつた.

\section{III 実 験 成 績}

\section{1. マウスにおける合成 TRF の効果 (Table 1)}

合成 TRF $50 \mathrm{ng}(0.05 \mu \mathrm{g}), 100 \mathrm{ng}(0.1 \mu \mathrm{g})$ （夫々マウス一頭当りの投与量）投与群では Blood radioactivity は投与 2 時間後に増加しての両群の增加率は生理食塩水投与群に比べ推計学上有意に高かつた. $50 \mathrm{ng}$ 投与

Table 1. Effect of synthetic TRF on $\mathrm{T}_{4}$ pretreated mice*

\begin{tabular}{l|c|c}
\hline \multicolumn{1}{c|}{ Treatment } & $\begin{array}{l}{ }^{131} \text { I Release from thyroid } \\
\text { gland of mice \% of initial } \\
\text { blood }{ }^{131} \text { I at 2hrs } \pm \text { S.E. }\end{array}$ & P Value \\
\hline Saline & $102.0 \pm 9.8$ & - \\
Synth. TRF 50ng & $214.0 \pm 25.3$ & $<0.005$ \\
Synth. TRF 100ng & $208.0 \pm 13.3$ & $<0,005$ \\
\hline
\end{tabular}

* 1) Mice were pretreated with $\mathrm{T}_{4} 1.0 \mu \mathrm{g} 24 \mathrm{hrs}$ before experiment

2) Synth. TRF were administered intravanously 
群と 100ng 投与群との間には差を認めなかつたがこれはマウス内因性 TRF の最大放出に基くためではない かと推定される.

2. ラットにおける合成 TRF の効果 (Table 2)

ラット $100 \mathrm{~g}$ 体重あたり $1.0 \mu \mathrm{g}, 5.0 \mu \mathrm{g}, 10.0 \mu \mathrm{g}$ の合成 TRF を投与すると夫々の群で投与 10 分後血漿 TSH 活性は上昇した。 ての TSH 上舁は生理食塩水投与群に比べいずれも推計学的に有意の上昇である。且つ $1.0 \mu \mathrm{g}, 5.0 \mu \mathrm{g}, 10.0 \mu \mathrm{g}$ の合成 TRF 投与量と TSH 上昇との間に用量反応関係が成立した.

3. ラットにおける合成 TRF に対する TSH 反応の時間経過 (Table 3)

合成 TRF $10.0 \mu \mathrm{g}$ 投与の場合のラット血漿 TSH の時間反応をみると 6 分で既に上昇を示すが 10 分で最

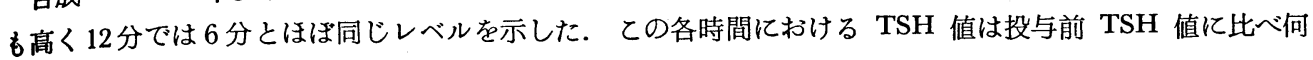
れも推計学上有意に高い。

4. ラット下垂体短時間インクベーションにおける TRF の効果 (Table 4)

Final incubation の Medium に添加した合成 TRF は下垂体より Medium 中に TSH を放出させ,

Table 2. Effect of synthetic TRF on rat* plasma TSH

\begin{tabular}{l|c|c}
\hline \multicolumn{1}{c|}{ Treatment } & $\begin{array}{l}\text { 131 I Release from thyroid } \\
\text { gland of mice, \% of initial } \\
\text { blood }{ }^{131} \text { I at 2hrs. } \pm \text { S.E. }\end{array}$ & P \\
\hline Saline & $67.0 \pm 8.2$ & - \\
Synth. TRF $1.0 \mu \mathrm{g}$ & $206.0 \pm 16.7$ & $<0.005$ \\
Synth. TRF $5.0 \mu \mathrm{g}$ & $230.2 \pm 22.8$ & $<0.005$ \\
Synth. TRF $10.0 \mu \mathrm{g}$ & $324.0 \pm 17.1$ & $<0.005$ \\
\hline
\end{tabular}

* 1) Rats were pretreated with $0.4 \mu \mathrm{g} \mathrm{T}_{4} 4 \mathrm{hrs}$ before experiment

2) Synth. TRF were administered intravenously and Blood samples for TSH assay were obtained from jugular vein 10 min. after TRF administration

Table 3. Time course of rat plasma TSH response after i.v. administration of synthetic TRF.

\begin{tabular}{c|c|c}
\hline Time & $\begin{array}{l}\text { 131I Release from thyroid } \\
\text { gland of mice, \% of initial } \\
\text { blood }{ }^{131} \text { I at 2hrs. } \pm \text { S.E. }\end{array}$ & P \\
\hline Before & $67.0 \pm 8.2$ & \\
6 min. after & $241.2 \pm 12.3$ & $<0.005$ \\
10 min. after & $324.0 \pm 17.1$ & $<0.005$ \\
12 min. after & $247.0 \pm 22.4$ & $<0.005$ \\
\hline
\end{tabular}

Table 4. Effect of synthetic TRF on incubated rat pituitary

\begin{tabular}{l|c|c}
\hline $\begin{array}{l}\text { Additon to } \\
\text { incubation medium* }\end{array}$ & $\begin{array}{l}\text { 131 I Release from thyroid } \\
\text { Gland, \% of initial blood } \\
{ }^{131} \mathrm{I} \text { at 2hrs. } \pm \text { S.E. }\end{array}$ & $\mathrm{P}$ \\
\hline Saline & $119.6 \pm 6.1$ & - \\
Symth. TRF $1.0 \mu \mathrm{g}$ & $175.2 \pm 2.5$ & $<0.005$ \\
\hline
\end{tabular}

* $2 \mathrm{ml}$ of Krebs Ringer Bicarbonate Glucose Buffer 
この場合の Medium TSH 濃度は対照として生理食塩水を添加した場合の Medium TSH 濃度より有意 に高い.

$$
\text { IV 考按 }
$$

\section{TRF の化学的性状}

TRF の化学的性状について1966年以前に知られていた点は視床下部よりの抽出純化の過程で Gel 沪過の のち有効分画の精製の段階ではアミノ酸を含んでいるととでてのような事実から TRF を polypeptide と 想定する研究者が多かつた ${ }^{6) \sim 8)}$. 即ち夫々の純化精製の段階で 4 種 $^{6 / 8)} 11$ 種 $^{7)} 7$ 種 $^{9)}$ のアミノ酸をもつている 事が報告され著者らを含む 3 研究機関で構成アミノ酸も共通した。 ての当時最も純化された TRF は Schally ${ }^{11)}$ による豚 TRF であり Glutamine, Histidine, Proline の3 種のアミノ酸をもつ事が報告されたがアミ ノ酸配列その他の構造特性を明らかにするためには至らなかつた。その後 1969 年に Schally ${ }^{10)}$ らは改めて 16.5万頭の豚視床下部より抽出純化を行ないての TRF が Glu, His, Pro, の 3 種のアミノ酸から成り夫々 が equimolar ratio で存在してアミノ酸配列は Glu-His-Pro であること及びその他の構造特性が判明した. ての高純化 TRF は in vivo で $\mathrm{ng}(\mathrm{m} \mu \mathrm{g})$, in vitro で pg $(0.001 \mathrm{~m} \mu \mathrm{g})$ で有効のあつたが, Glu-His-Pro を始めとする 3 種アうノ酸によるその他の配列をもつた合成 peptide には TRF 効果が認められなかつた という. 1969年秋に Folkers ${ }^{5}$ らは上述その他の TRF の構造特性を考虑に入れて Pyro-glutamylhisdilproline Amide [(pyro)-Glu-His-Pro $\left(\mathrm{NH}_{2}\right)$ ] を合成し $\mathrm{T}_{3}$ 前処置マウスで TRF 活性を検定し極めて高い TRF 活性を証明したが吾々も (pyro) Glu-His-Pro $\left(\mathrm{NH}_{2}\right)$ がマウス，ラットによる in vivo 検定，in vitro 検定の 3 検定法に於て TRF 効果を有するととを確認した.

\section{2. 合成 TRF の生物作用}

Folkers らは上記の Tripeptide である合成 TRF の生物作用について検討し速報しているがその詳細は 必ずしも明らかではない。

先づ合成 TRF の有効量を前述した高純化 TRF のそれと比較しているが in vivo における $\mathrm{T}_{3}$ 前処于 マウス法で $6 〜 54 \mathrm{mg}$ の投与量で TRF 効果を発揮してれは 2〜8〜18ng の高純化豚 TRF の効果とほぼ 等しい事をみている，今回吾々の成績でもマウス法で50ng で既に有効であり合成 TRF は高純化 TRF と ほぼ等しい用量力価関係をもつといえる，in vivo ラット法で Folkers はその有効量を報告していないが吾 々は合成 TRF が $1 \mu \mathrm{g}$ で既に有効である事を確誌した。これはラットにおける検定の最低可能值である. ラットでは投与合成 TRF 量 $1.0 \sim 10.0 \mu \mathrm{g}$ と TSH 放出との間に用量反応関係が成立するととを認めた. 又, 合成 TRF 投与後の TSH 反応の時間的推移をみると 6 分，10分，12分後の反応では10分にピークを認め, これは著者らが抽出した牛 TRF にわける所胃 ${ }^{2)}$ と全く等しい.

更にラット下垂体短時間インクベィション法を利用した in vitro の検定法でも合成 TRF は有効であつ たので，(1) 用量反応関係の存在 (2) in vivo, in vitro の効果の一致性 (3) 反応の時間経過の諸点に於て 合成TRFのもつ効果が特異的なものであるてとを強く支持する結果であつたがての点については更にTSH 賦活化作用, TSH 不活化抑制作用, 甲状腺レベルでの直接作用, 内因性 TRF 放出作用等を合成 TRF が もたないか否かを確める必要があり，吾々はての点にも研究を進めており第 2 編に述べたい.

\section{$\mathrm{V}$ 結 論}

Folkers らの合成になる Tripeptide [(pyro) Glu-His-pro $\left.\left(\mathrm{NH}_{2}\right)\right]$ の TRF 効果を観察し以下の結果を得 た.

1. $\mathrm{T}_{4}$ 前処置マウスに於て合成 TRF は50ng の投与量で TSH 放出効果を示した.

2.ラットに於て合成 TRF は $1.0 \mu \mathrm{g}$ の投与量で TRF 効果を示し且つ $1.0 \sim 10.0 \mu \mathrm{g}$ の範囲で投与量と TSH 放出との間に用量反応関係を認めた。 又 TSH 放出は合成 TRF 投与後10分に於て最大であつた.

3.ラット下垂体短時間インクベーションによる in vitro の条件下でも合成 TRF は有効であつた. 
4. 用量反応関係の存在, in vivo in vitro にわける効果の一致, 反応の時間経過等の点で合成 TRF の 作用が特異的なものである事が推定される.

文献

1) Redding, T.W., Bowers, G.Y., and A.V. Schally : Endocr. 79 : 229, (1966)

2）佐古田雅弘

: 第17回日本医学会総会学術講演集 III, pp.322, 1967.

3) Saffran, M., and A.V. Schally : Canad.

J. Bioch. Physiol. 33 : 408, (1955)

4) McKenzie, J.M. : Endocr. $63: 372$, (1958)

Folkers, K., F. Enzmann, J. Boler, G.Y. Browers and A.V. Schally : Bioch. Biophysic. Comm. 37 : 123, (1969) 6) Schally, A.V., C.Y. Bowers, and T.W. Redding : Endocr. 78 : 72.6, (1966)

7) Guillemin, R., E. Sakiz, and D.N. Ward : Proc. Soc. Exp. Biol. Med. $118: 1132$, (1965) 8) Tsuji, S., M. Sakoda, and M. Asami : In "Integrative mechanism of neuroendocrine system" (Itoh, S. ed.) Hokkaido Univ. Med. Libe. Ser. pp. 63, Sapporo, (1968) $\quad$ 9) Schally, A.V., T.W. Redding, J.F. Barrett, and C.Y. Bowers : Fed. Proc. 25 : 348, (1966)

10) Schally, A.V., T.W.

Redding, C.Y. Bowers, and J.F. Barrett : J. Biol. Chem. $244: 4077$, (1969) 11 ) Schally, A.V., Bowers, C.Y., Redding, T.W., and J.F. Barrett : Bioch. Biophys. Res. Comm. 25 : 165, (1966) 


\title{
合成視床下部ホルモン TRF (Thyrotropin-Releasing
}

\author{
Factor）の生物作用にかんする研究
}

第 2 篇 合成 TRF の生物作用の特異性及び作用修飾因子

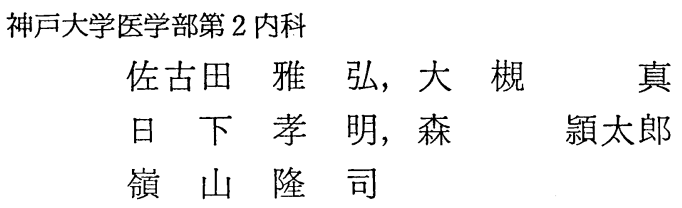

(昭和 45 年 7 月 1 日受付)

Folkers らの合成になる Tripeptide (py ro-glutamylhistidilproline amide) の TRF 作用を観察 しての合成 TRF が TSH の賦活作用をもたず，TSH 㥞作用を有せず，既報のように投与量と TSH の反応との間に用量反応関係を有し in vivo と in vitro での効果の一致性からみてその TRF 作用 は特異的なものである事を証明した．合成 TRF は $\mathrm{T}_{4}$ によつて抑制を受けての $\mathrm{T}_{4}$ の抑制作用は $\mathrm{T}_{4}$ 投与量と合成 TRF 投与量とに容量依存的である.

\section{1 緒䇾}

下垂体 TSH 分泌の調節に働く視床下部起源の液性因子が TRF と呼ばれ，その抽出分離への努力が続 けられて来た. 1969年までの数年間にわたる諸家の研究 ${ }^{122) 3}$ とより TRF が Glutamine, Histidine, Proline の 3 アミノ酸を含むてとその他の構造特性が判明し1969年秋には Folkers らによつて合成された pyro Glutamylhistidilproline Amide [ (pyro) Glu-His-Pro $\left(\mathrm{NH}_{2}\right)$ ] と呼ばれる Tripeptide 亿 TRF 作用が ある事が報告された。

との様な経過途上に TRF がホルモンとしての条件を満し Thyrotropin-Releasing Hormone (TRH) ${ }^{4)}$ と呼ばれるようになつた．てのように合成 TRF の生物作用特異性を検討するてとはホルモンとしての位置 性格を想定する場合には不可欠であると考えられるがての点については合成者である Folkers らの報告でも 不詳である. 第 1 篇で Folkers より提供された合成 TRF の in vivo, in vitro にわける効果を锥察したが 本篇では合成 TRF の作用特異性の娭討に通じる作用点, 作用機序, 作用修飾因子等の点を明らかにしたい.

\section{II 実 験 方 法}

\section{1. 実験動物}

体重 13-15g の DD 系雌マウス, 体重 120-130g の Swiss Webster 系雄ラットを低ヨード含有飼料及び 蒸溜水にて飼育したものを用いた。

2. TRF 検定法

a) in vivo マウス法：ラベル甲状腚ホルモン放出による血中放射能変動を指標とする Redding ${ }^{133}$ 変法に よつた. 即ち実験 2 日前に $5 \mu \mathrm{ci}{ }^{131} \mathrm{INa}$ を腹腔内投与, 1 日前に $\mathrm{T}_{4} 1.0 \mu \mathrm{g}$ を皮下注し実験当日前採血のの ち検体を静注し 2 時間後再度採血して両者の Bloodradioactivity を测定，增加率を\%で表した．

b) in vivo ラット法：血墏 TSH の変動を指標とする佐古田 ${ }^{14)}$ の方法によつた. 即ち実験 4 時間前に 
T、0.4 $\mathrm{g} / 100 \mathrm{~g}$ 体重を皮下注射しペントバルビタール麻酔下に頸静脈より検体投与後10分で採血し TSH 検 定に供した.

c) in vitro ラット法（下垂体短時間インクベーション法）：Saffran ${ }^{15}$ 変法によつた. 即ち 3 頭からのラ ット下垂体前葉を狭部にて正確に 2 等分し Krebs-Ringer-Bicarbonate-Glucose (200mg/dl)-Buffer (以下 KRBG と略す）（pH=7.2） $2 \mathrm{ml}$ を入れた容量 $25 \mathrm{ml}$ の 2 つフラスコに夫々 3 半切片を別々に入れ実験群 及び対照群とした．95\% $\mathrm{O}_{2}-5 \% \mathrm{CO}_{2}$ にてフラスコを充し $37^{\circ} \mathrm{C} に て 60$ 分の Preincubation を行なつたのち 下垂体を別のフラスコに入れ実験群には検体を添加した KRBG 液にて Final incubation を60分行ない Medium 内の TSH 活性を実験群と対照群で比較した. (Paired incubation)

\section{TSH 测定法}

McKenzie 変法 ${ }^{16)}$ によつた. 最低測定可能值は 0.1 musp, 精度指数は 1.359 である

4. 合成 TRF

Dr. Folkers ${ }^{17)}$ の合成, 提供によるもの (IBR 228, Institute for Biomed. Research, Univ. of Texas) で 構造は Pyroglutamylhistidilproline amide [ (pyro) Glu-His-Pro $\left(\mathrm{NH}_{2}\right)$ ] であり使用に際しては生理食 塩水に溶解した。

\section{5.下垂体剔除}

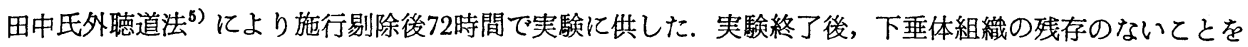
確認した.

\section{6. 結果の推計学的処理}

in vivo, in vitro で放出された TSH の検定には 1 群 6-8匹のマウスを使用し群間の差の検証はStudent の $\mathrm{t}$ test によつた.

\section{III 実 験 結 果}

\section{A. 合成 TRF の作用特異性にかんする観察}

1) 合成 TRF の TSH 賦活作用の否定 (Table 1)

合成 TR が TSH 賦活作用を有していてその結果, 一見 TSH 放出効果をもつ如く認識される危険を除 くため牛 TSH (Thhytropar, Armour) と TRF を混合し 15 分間 $37^{\circ} \mathrm{C} に て$ incubate しその後にマウスに 投与した. との結果合成 TRF は TSH の㒃活効果を全く有しなかつた.

2) 合成 TRF の TSH 様作用の否定 (Table 2)

合成 TRF が甲状脉レベルに働いて TSH 様作用を発揮するため一見 TSH 放出效果をもつ如く認識され る危険を除くため (a) TSH 検定のための前処置を受けたマウス（即ち $10 \mu \mathrm{g} \mathrm{T}$ により内因性 TSH 放出 は抑制されたマウス）に合成 TRF を投与. (b) 下垂体剔除ラットに合成 TRF を投与しその血漿を TSH 検定，の2つの点を検討したが何れの場合にも TSH 様作用を全く認めなかつた。

B. 合成 TRF に対する Thyroxine の影響 (Table 3)

Table 1. Absence of potentiation for TSH by synthetic TRF

\begin{tabular}{|c|c|c|}
\hline Preparation & $\begin{array}{l}{ }^{131} \text { I Release from thyroid } \\
\text { Gland of mice, } \% \text { of initial } \\
\text { blood }{ }^{131} \mathrm{I} \text { at } 2 \mathrm{hrs} . \pm \mathrm{S} . \mathrm{E} \text {. }\end{array}$ & $\mathbf{P}$ \\
\hline beef $\mathrm{TSH}^{*} 0.2 \mathrm{mUSP}$ & $147.0 \pm 13.9$ & - \\
\hline lbeef TSH $0.2 \mathrm{mUP}+\mathrm{TRF} 10 \mu \mathrm{g}$ & $186.0 \pm 15.0$ & N.S. \\
\hline beef TSH $0.4 \mathrm{mUSP}$ & $249.0 \pm 26.0$ & $\longrightarrow$ \\
\hline lbeef TSH $0.4 \mathrm{mUSP}+\mathrm{TRF} 10 \mu \mathrm{g}$ & $244.0 \pm 19.5$ & N.S . \\
\hline
\end{tabular}

* Thytropar (Armour pharmac. Co.) were used as beef TSH preparation 
Table 2. Absence of TSH activity of synthetic TRF

\begin{tabular}{|c|c|c|c|}
\hline Preparation & Animal & $\begin{array}{l}{ }^{131} \text { I Release from thyroid } \\
\text { Gland, } \% \text { of initial blood } \\
{ }^{131} \text { I at } 2 \mathrm{hrs} . \pm \text { S.E. }\end{array}$ & $P$ \\
\hline Saline & Untreated rat & $67.0 \pm 8.2$ & - \\
\hline Synth. TRF $10 \mu \mathrm{g}$ & Untreated rat & $324.0 \pm 17.1$ & $<0.05$ \\
\hline Synth. TRF $5 \mu \mathrm{g}$ & Hypophysectomized rat & $87.5 \pm 4.1$ & N.S. \\
\hline Synth. TRF $10 \mu \mathrm{g}$ & Hypophysectomized rat & $88.6 \pm 5.4$ & N.S. \\
\hline Saline & $\mathrm{T}_{4}$ pretreated mice & $80.0 \pm 6.0$ & - \\
\hline Synth. TRF $0.1 \mu \mathrm{g}$ & $\mathrm{T}_{4}$ pretreated mice & $105.0 \pm 7.4$ & N.S. \\
\hline
\end{tabular}

Table 3. Effect of increasing dose of $\mathrm{T}_{4}$ on synthetic TRF activity

\begin{tabular}{r|c|c}
\hline \multicolumn{1}{c|}{ Treatment } & $\begin{array}{c}{ }^{131} \text { I Release from thyroid } \\
\text { Gland, \% of initial blood }\end{array}$ & $\mathbf{P}$ \\
\hline No $\mathrm{T}_{4}+$ Synth. TRF $1.0 \mu \mathrm{g}$ & $236.2 \pm 11.0$ & - \\
$1.0 \mu \mathrm{g} \mathrm{T}_{4}+$ Synth. TRF $1.0 \mu \mathrm{g}$ & $262.2 \pm 11.2$ & N.S . \\
$3.0 \mu \mathrm{g} \mathrm{T}_{4}+$ Synth. TRF $1.0 \mu \mathrm{g}$ & $172.2 \pm 7.7$ & $<0.005$ \\
\hline No $\mathrm{T}_{4}+$ Synth. TRF $10.0 \mu \mathrm{g}$ & $263.0 \pm 22.3$ & - \\
$1.0 \mu \mathrm{g} \mathrm{T}_{4}+$ Synth. TRF $10.0 \mu \mathrm{g}$ & $251.0 \pm 20.0$ & N.S . \\
$3.0 \mu \mathrm{g} \mathrm{T}_{4}+$ Synth. TRF $10.0 \mu \mathrm{g}$ & $187.6 \pm 4.7$ & $\mathrm{~N} . \mathrm{S}$. \\
$10.0 \mu \mathrm{g} \mathrm{T} \mathrm{T}_{4}+$ Synth. TRF $10.0 \mu \mathrm{g}$ & $172.5 \pm 12.7$ & $<0.025$ \\
\hline
\end{tabular}

予め 4 時間前にラットに種々の量の Thyroxine（以下 $\mathrm{T}_{4}$ ）を皮下注射し種々の量の合成 TRF を投与し て血中 TSH の変動をみた. 合成 TRF $1.0 \mu \mathrm{g}$ 投与の場合は予め投与した $\mathrm{T}_{4} 3.0 \mu \mathrm{g}$ ，により TRFの TSH 放出作用は抑制された. 一方合成 TRF $10.0 \mu \mathrm{g}$ 投与では予め投与した $\mathrm{T}_{4} 3.0 \mu \mathrm{g}$ ，により TRF の TSH 放 出作用は抑制を受けず $\mathrm{T}_{4} 10.0 \mu \mathrm{g}$ 投与で初めて抑制された。即ち $\mathrm{T}_{4}$ は合成 TRF 作用を抑制するがての抑 制は予め投与する $\mathrm{T}_{4}$ 量と合成 $\mathrm{TRF}$ の投与量とに容量依存的であるといえる.

$$
\text { IV 考按 }
$$

\section{1. 合成 TRF の作用特異性}

TRF の存在が想定されその抽出分離の過程で問題となつたのは TRF 効果の検定に於て特異的な TRF

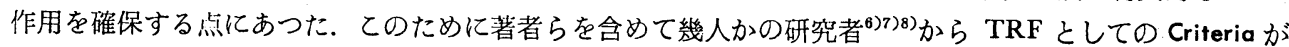
提示された。 その目的とするとてろは下垂体に作用点を有して（即ち内因性 TRF の動員に働かず, 且つ用 状腺レベルに働くのではなく）TSH を放出させ（即ち TSH の賦活化又は不活性化の抑制に働かず）ホル モンの特徴である用量反応関係と一定の作用パタンをもつ事実を確保するにある．との視点からみて合成 TRF の特異性に対する検討は重姴と思われる，がての点については Folkers らも明らかにしていない，著 者らは前述の様に合成 TRF がTSH の賦活作用をもたず，又甲状腺レベルに働く TSH 様作用を有せず， 且つ生理的刺激である寒冷に対する $\mathrm{TSH}$ 反応を抑制しうる $\mathrm{T}_{4}$ 量の前処置下 ( $1 \sim 5 \mu \mathrm{g}$ の $\mathrm{T}_{4}$ 前処置) に於 ても合成 TRF がTSH 放出を引起す事実を明らかにしたがての事実は合成 TRF の作用特異性を強く支 持するものと考えられる．更に第 1 篇で述べた用量反応関係の存在，in vivo，in vitro の一致性を加える とここに合成 TRF の作用特異性は確保されたといえる.

\section{2. 合成 TRF に対する Thyroxine の影響}




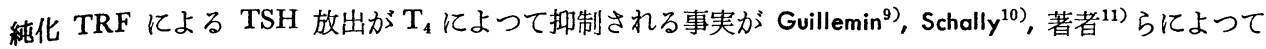
指摘されている. 即ち $\mathrm{T}_{4}$ の投与量を次第に増加して，一方 TRF の種々の量を与えると一定量の $\mathrm{T}_{4}$ 前処 直では一定量の TRF の TSH 放出作用が抑制される. 逆に TRF 投与量を次第に増加するてとによつて T、による抑制を突破して TSH 放出を起す。ここには TRF と $\mathrm{T}_{4}$ との間に dose dependent な negative interaction と呼ばれるべき関係が存在するといえる.今回合成 TRF について $T_{4}$ の影響を镜察したが合 成 TRF についても全く同様の事実が認められた。即ち実験成績にみるように合成 TRF $1.0 \mu \mathrm{g}$ の効果は $\mathrm{T}_{4}$ $3.0 \mu \mathrm{g} ， \sigma$ 前処置で抑制されている。合成 TRF 投与を $10.0 \mu \mathrm{g}$ に増進すると $\mathrm{T}_{4} 3.0 \mu \mathrm{g}$ ，では抑制を受けず $10.0 \mu \mathrm{g}$ の $\mathrm{T}_{4}$ で初めて TRF 作用抑制の傾向を示す.

前述のような T、による純化 TRF 作用抑制の背景には下垂体の蛋白代謝に関連する機序が想定され著者 らも且つて報告した ${ }^{12)}$ がての点について合成 TRF を使用して $\mathrm{T}_{4}$ の抑制機序を検討する必要があると考え られる.

\section{$\mathrm{V}$ 結 論}

Folkers の合成になる Tripeptide [(pyro) Glu-His-Pro $\left(\mathrm{NH}_{2}\right)$ ] の TRF 作用の特異性及び作用修飾因子 について検討し以下の結果を得た.

1. 合成 TRF は牛 TSH 亿対する賦活作用をもたない.

2. 合成 TRF は TSH 样作用をもたない。

3. TSH 賦活作用，TSH 様作用をもたず且つ前編に述べた合成 TRF 投与量と TSH 放出との間の用 量反応関係, in vivo, in vitro に於ける効果の一致性, 特幑的な TSH 放出の時間経過と併せ考え合成 TRF の作用は特異的なものであるといえる.

4. $T_{4}$ は合成 $T R F$ の作用を抑制する。 この $T_{4}$ の抑制作用は前投与する $T_{4}$ 量と合成投与 $T R F$ 量に容 舅依存的である.

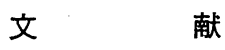

1) Schally, A.V., T.W. Redding, C.Y. Bowers, and J.F. Barrett : J. Biol. Chem. 244, 4077, (1969)

2) Burgus, R., Stillwell, R.N. McCkloskey, J.A., Ward, D.N., Sakiz, E., and R. Guillemin : The physiologist $9: 149$, (1966) $\quad$ 3) Tsuji, S., M. Sakoda, and M. Asami : In"Integrative mechanism of neuroendocrine system" (Itoh, S.ed.) Hokkaido Univ. Med. Libr. Ser. pp. 63, Sapporo, (1968). 5）田中 明：境之義研究所年報, 第 5 号，(1957). 6) Guillemin, R. : Rec. Prog. Hor. Res. $20: 89$, (1964). $\quad$ 7) McCann, S.M. and Dhariwal, A.P.S. : In "Neuroendocrinology I”Acad. Press pp. 261, (1966). 8) 佐古田雅弘：日本医師会雑誌，60；561，(1968). 9) Vale, W., R. Burgus, and R. Guillemin : Proc. Soc. Exp. Biol. Med. $125: 210$, (1967). 10) Bowers, C.Y., Schally, A.V. Reynolds, G.A. and D.W. Hawley : Endocr. 81 : 741, (1967). 11) Tsuji, S., M. Sakoda, and T. Okuno : Proc. 3rd Asia Ocean. Cong. Endocr. part II, 362, (1967). 12) Tsuji, S., Sakoda, and H. Fukatsu : Endocr. Jap. Supp. I, 35, (1969). 13) Redding, T.W., Bowers, C.Y., and A.V. Schally : Endocr. $79: 229$, (1966). 14) 佐古田雅弘：第17回日本医学会 総会学術講演集 III, pp. 322, (1967). 15) Saffran, M., and A.V. Schally: Ganad. J. Bioch. Physiol. 33 : 408, (1955). 16) McKenzie, J.M.: Endocr. $63: 372$, (1958). 17) Folkers, K., F. Enzmnn, J. Boler, C.Y. Bowers and A.V. Schally : Bioch. Biophysic. Res. Comm. $37: 123$, (1969). 